\title{
Hemangioma of the cavernous sinus in a child
}

Figure Hemangioma of the cavernous sinus
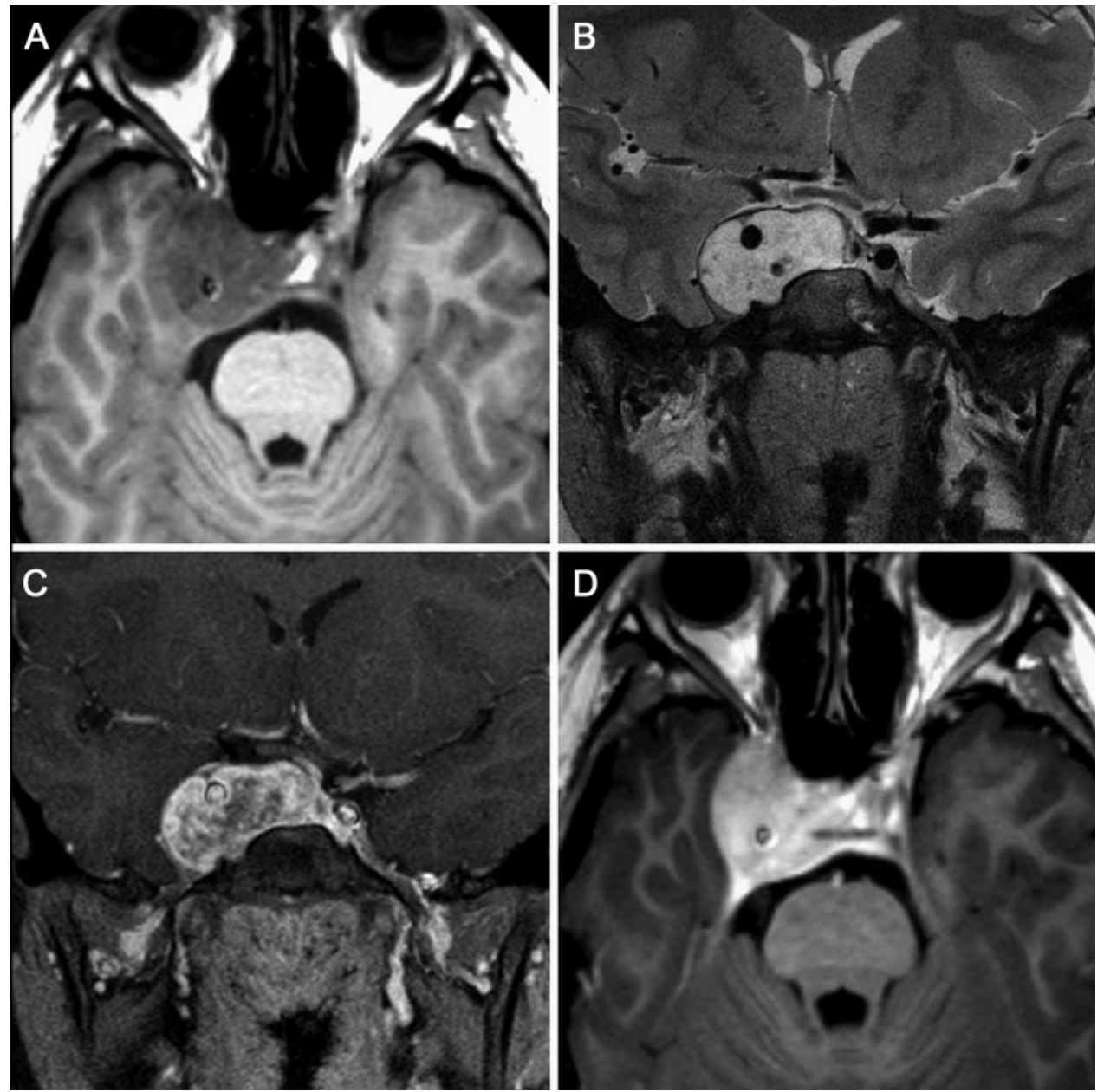

Axial T1-weighted (A) and coronal T2-weighted (B) images show an expansile $3.5 \times 2.6 \mathrm{~cm}$ tumor in the right cavernous sinus with T1 hypointense and marked T2 hyperintense signal. Coronal (C) and axial (D) contrast T1-weighted images acquired several minutes apart reveal characteristic early heterogeneous and late homogeneous enhancement.

An 11-year-old boy presented with diplopia and right cranial nerve VI paresis. MRI demonstrated a T2hyperintense extra-axial mass in the cavernous sinus. Early heterogeneous enhancement progressed to late homogeneous enhancement. The carotid artery was not narrowed (figure). Slow growth prompted endoscopic transsphenoidal resection. Microscopy demonstrated a vascular tumor with bland endothelial cells and no mitoses.

Hemangiomas of the cavernous sinus rarely occur in children. Marked T2 hyperintensity and progressive nodular centripetal enhancement are common. ${ }^{1}$ Preoperative diagnosis is important to avoid hemorrhage at surgery. They are often mistaken for more common meningiomas, which usually show T2-isointensity and carotid artery narrowing.

P. Litkowski, BA, Y. Khakoo, MD, S. Gilheeney, MD, M. Souweidane, MD, J. Huse, MD, S. Haque, MD, R.J. Young, MD, New York, NY 
Author contributions: $P$. Litkowski: analysis or interpretation of data, drafting/revising the manuscript for content, including medical writing for content. Dr. Khakoo: analysis or interpretation of data, drafting/revising the manuscript for content. Dr. Gilheeney: analysis or interpretation of data, drafting/revising the manuscript for content. Dr. Souweidane: acquisition of data, analysis or interpretation of data. Dr. Huse: acquisition of data, analysis or interpretation of data. Dr. Haque: analysis or interpretation of data. Dr. Young: study concept or design, acquisition of data, analysis or interpretation of data, drafting/revising the manuscript for content, including medical writing for content. Dr. Young takes full responsibility for the data, analyses and interpretation, and the conduct of the research, and has full access to all of the data, with the right to publish all data separate and apart from any sponsor.

Disclosure: P. Litkowski reports no disclosures. Dr. Khakoo serves on the editorial board of the Journal of Child Neurology. Dr. Gilheeney reports no disclosures. Dr. Souweidane serves as a consultant for Aesculap, Inc. and receives research support from United Therapeutics, Beez Foundation, St. Baldrick's Foundation, Cure Starts Now Foundation, Dana Foundation, Christian Rivera Foundation, and Matthew Larson Foundation. Dr. Huse receives research support from Society of MSKCC, American Association for Cancer Research, Geoffrey Beene Foundation, and Leon Levy Foundation. Dr. Haque reports no disclosures. Dr. Young serves as an Associate Editor for the Journal of Pediatric Neuroradiology and World Journal of Neurology; and receives research support from MSKCC Department of Radiology and Radiological Society of North America.

Address correspondence and reprint requests to Dr. Robert J. Young, Memorial Sloan-Kettering Cancer Center, 1275 York Avenue, MRI-1156, New York, NY 10065; youngr@mskcc.org

1. Jinhu Y, Jianping D, Xin L, Yuanli Z. Dynamic enhancement features of cavernous sinus cavernous hemangiomas on conventional contrast-enhanced MR imaging. AJNR Am J Neuroradiol 2008;29:577-581.

\section{NeuroImages Are Free at www.neurology.org!}

All Neurology ${ }^{\circledR}$ NeuroImages can now be freely accessed on the Neurology Web site. See them at www.neurology.org, where you can also sign up for journal email alerts and check out other online features, including the Resident \& Fellow section, Neurology: Clinical Practice, and the weekly Neurology Podcasts.

\section{Neurology ${ }^{\circledR}$ Launches WriteClick Join the Debate!}

Neurology.org has launched WriteClick and the editors encourage comments about recent articles.

Go to www.neurology.org and click on the "WriteClick" tab at the top of the page. Responses will be posted within 72 hours of submission.

Before using WriteClick, remember the following:

- WriteClick is restricted to comments about studies published in Neurology within the last eight weeks

- Read previously posted comments; redundant comments will not be posted

- Your submission must be 200 words or less and have a maximum of five references; reference one must be the article on which you are commenting

- You can include a maximum of five authors (including yourself) 


\title{
Neurology
}

\author{
Hemangioma of the cavernous sinus in a child \\ P. Litkowski, Y. Khakoo, S. Gilheeney, et al. \\ Neurology 2011;77;1647-1648 \\ DOI 10.1212/WNL.0b013e3182343399
}

This information is current as of October 24, 2011

\section{Updated Information \& Services}

References

Subspecialty Collections

Permissions \& Licensing

Reprints including high resolution figures, can be found at: http://n.neurology.org/content/77/17/1647.full

This article cites 1 articles, 1 of which you can access for free at: http://n.neurology.org/content/77/17/1647.full\#ref-list-1

This article, along with others on similar topics, appears in the following collection(s):

\section{All Oncology}

http://n.neurology.org/cgi/collection/all_oncology

All Pediatric

http://n.neurology.org/cgi/collection/all_pediatric

MRI

http://n.neurology.org/cgi/collection/mri

Primary brain tumor

http://n.neurology.org/cgi/collection/primary_brain_tumor

Information about reproducing this article in parts (figures,tables) or in its entirety can be found online at:

http://www.neurology.org/about/about_the_journal\#permissions

Information about ordering reprints can be found online:

http://n.neurology.org/subscribers/advertise

Neurology ${ }^{\circledR}$ is the official journal of the American Academy of Neurology. Published continuously since 1951, it is now a weekly with 48 issues per year. Copyright Copyright (? 2011 by AAN Enterprises, Inc.. All rights reserved. Print ISSN: 0028-3878. Online ISSN: 1526-632X.

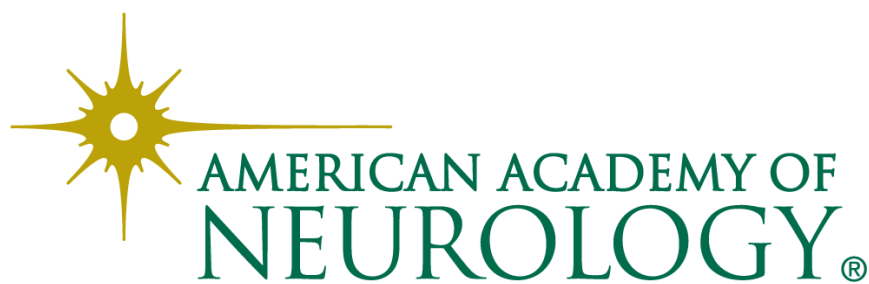

